\title{
The measurement of primary productivity in a high-rate oxidation pond (HROP)*
}

\author{
T.Berner ${ }^{1}$, Z.Dubinsky ${ }^{1}$, F.Schanz ${ }^{2}$, J.U.Grobbelaar ${ }^{3}$, H.Rai ${ }^{4}$, U.Uehlinger ${ }^{5}$ \\ and P.G.Falkowski ${ }^{6}$
}

${ }^{1}$ Department of Life Sciences, Bar-Ilan University, Ramat-Gan, 52100, Israel, ${ }^{2}$ Hydrobiologisch-Limnologisch Station, CH-8802 Kilchberg, Switzerland, ${ }^{3}$ Institute for Environmental Sciences, PO Box 339, Bloemfontein. South Africa, ${ }^{4}$ Max Planck Institute für Limnologie, Postfach 165, 2320 Plön, GFR, ${ }^{5}$ Lake Research Laboratory EAWAG/ETH, 6047 Kastanienbaum, Switzerland, and ${ }^{6}$ Oceanography Department, No. 318 , Brookhaven National Laboratory, Upton, NY 11973, USA

*This paper is the result of a study made at the Group for Aquatic Primary Productivity (GAP), Second International Workshop held at the TechnionIsrael Institute of Technology in Haifa in May 1984

\begin{abstract}
A high-rate oxidation pond is studied as a model system for comparing ${ }^{14} \mathrm{C}$ and oxygen evolution methods as tools for measuring primary productivity in hypenropnic aquatic systems. Our results indicate that at very dense algal populations (up to $5 \mathrm{mg}$ chl. $a 1^{-1}$ ) and high photosynthetic rates, ${ }^{14} \mathrm{C}$ based results may severely underestimate primary productivity, unless a way is found to keep incubation times very shor. Results obtained with our oxygen electrode were almost an order of magnitude higher than those obtained by all ${ }^{14} \mathrm{C}$ procedures. These higher values correspond fairly well with a field-tested computer-simulation model, as well as with direct harvest data obtained at the same pond when operated under similar conditions. The examination of the size-fractionation of the photosynthetic activity underscored the imponant contribution of nannoplanktonic algae to the total production of the system.
\end{abstract}

\section{Introduction}

Hypertrophic, aquatic ecosystems may be loosely described as containing high concentrations of inorganic compounds, which cause profuse growth of various organisms. The most prominent of such systems are the many lakes where enrichment in nitrogen and phosphorus results in massive algal blooms. Such enrichment may be natural, as it is in the East African soda lakes, due to agricultural runoff or a consequence of contamination by domestic and industrial wastewaters.

One such rather well-documented hypertrophic ecosystem is the oxidation lagoon, designed basically as a means for wastewater treatment in areas where light is not a limiting factor. In such lagoons, or their accelerated version, the high-rate oxidation ponds (Oswald and Gotaas, 1955; Oswald, 1963), bacterial populations mineralize the incoming organic matter thereby making it available for algal utilization. The permanent 'algal blooms' in such ponds assimilate the various nutrients, preventing undesirable eutrophication in receiving water bodies. Algal photosynthesis produces the oxygen which keeps the water from becoming anoxious and allows the bacteria fast aerobic growth and activity (Hendricks and Pote, 1974). Algal mass culture installations, which could be defined as artificial hypertrophic aquatic environments, have been studied worldwide (Goldman, 1979a). These ponds are optimized for growing microalgae as 
feed for edible aquatic invertebrates, fish, poultry and cattle, either entirely or as part of integrated systems combined with sewage treatment (Dubinsky et al., 1978; Dubinsky and Aaronson, 1980). Lately, the possible use of microalgae as a source of chemicals, such as proteins, lipids, enzymes and antibiotics (Aaronson et al., 1980; Berner et al., 1980), resulted in intensified research efforts, summarized earlier in Burlew (1953) and more recently in Shelef and Soeder (1980). The research focused on the scientific point of view (Goldman, 1979b) in such areas as biochemistry, physiology, ecology and genetics, as well as on the technical and economical aspects of the utilization of these organisms (Benemann et al., 1980; Dubinsky et al., 1980; Mohn, 1980; Moraine et al., 1980; Soeder, 1980).

Due to high concentrations of the algae and other suspended particles and dissolved substances, all such hypertrophic systems are characterized by a very low light penetration resulting in a shallow euphotic zone (Talling et al., 1973; Melack and Kilham, 1974; Berner et al., 1979). This phenomenon significantly affects the total primary production of the algae in such habitats.

Direct biomass measurement over time intervals, is the most common way of measuring primary production in raceway systems (Grobbelaar, 1981).

Two additional techniques and their modifications are usually used for the measurement of primary production of phytoplankton. These techniques are based either on $\mathrm{O}_{2}$ evolution, e.g. dark and light bottles (Gaarder and Gran, 1927) or on ${ }^{14} \mathrm{C}$ incorporation (Steemann Nilsen, 1952). The theoretical and practical differences between these methodologies are discussed by Sakamoto et al. (1984), summarizing experimental results of the 1982 GAP workshep. The dense algal population and the resulting extremely shallow photic zone common to all hypertrophic systems pose difficult problems in the measurement of the primary productivity by all methods.

A few models based on experimental data have been developed in order to predict algal growth rates in outdoor mass cultures. Some models only consider light influence (Goldman, 1979b; Märkl, 1980), whilst others also include temperature variations (Grobbelaar, 1981; Hill and Lincoin, 1981; Toerien, 1981). The model of Shelef (1982) includes the above variables, as well as variations in the organic carbon, total nitrogen and total phosphorus content of the water. Grobbelaar et al. (1984) refined the deterministic model of Grobbelaar (1981) and calibrated it against 18 months of field data obtained in five outdoor ponds, ranging in surface area to $71-164 \mathrm{~m}^{2}$ with culture depth of $0.12-0.15 \mathrm{~m}$.

Recently, in-situ primary production of natural phytoplankton populations and their subsequent size fractionation have received much attention because of the influence of particle size on the population dynamics of phytoplankton and their interactions with the heterotrophic and grazing organisms in both the fresh-water and marine environments. However, no such studies have been attempted in any hypertrophic system.

The importance of the contribution of the nannoplankton to the total photosynthesis of the phytoplankton population has been reported earlier (Holmes, 1958; Kalff, 1972; Kristiansen, 1971; Munawar and Munawar, 1975; Munawar and Burns, 1976).

The prevalence of nannoplankton could have far-reaching implications, particularly in terms of algal metabolism, decomposition, production, biomass relationships and nutrient cycling (Gilmartin, 1964; Anderson. 1965; Eppley and Sloan, 1966; Parson 
and Lebrasseur, 1970; Durbin et al., 1975; Malone, 1977; Paerl and Mackenzie, 1977; Berman, 1978; Conover, 1978; Herbland and Bouteiller, 1981).

Comparing the results presented by Heaney and Sommer (1984) on phytoplankton size analysis (microscopic analysis) and results of Rai's experiments during the GAP I workshop (Sakamoto et al., 1984) on the C-uptake of different size fractions in Lake Constance clearly demonstrates that nannoplankton $(<10 \mu \mathrm{m})$ were not only dominant in phytoplankton communities, but also showed high photosynthetic rates, suggesting their important role in the algal community dynamics.

Vertical variation in the primary production rates by different size fractions showed that the smaller size fraction, especially $<10 \mu \mathrm{m}$, played an extremely important role in the phytoplankton community metabolism of the lake studied (Rai, 1982, 1984).

It might be suggested here that the $<10 \mu \mathrm{m}$ (nannoplankton) fraction may possess characteristic and flexible nutrient kinetics adapted to microscale variations in light, temperature and nutrient conditions and that their high surface/volume ratio gives them an advantageous position in extreme environmental conditions.

The delicate flagellates (especially in the high-rate oxidation ponds) and $\mu$-algae have therefore greater influence upon the metabolic exchange throughout the epilimnion and metalimnion, particularly in deeper lakes, as opposed to the larger size phytoplankton (netplankton), since the organisms $<10 \mu \mathrm{m}$ (nannoplankton) generally have higher reproduction and decomposition rates and lower rates of sinking (Pavoni, 1963).

This paper is devoted to the comparison of some of the methods used at the second GAP workshop held in Haifa, Israel. Possible reasons for the discrepancies occurring between data obtained by different methods and their adequacy for the study of hypertrophic systems are discussed. We also compare the various data sets with the values predicted by the proposed model of Grobbelaar et al. (1984).

\section{Materials and Methods}

\section{Research area}

The experiments were carried out at the experimental $120 \mathrm{~m}^{2}$ high-rate oxidation pond at the Technion-Israel Institute of Technology in Haifa on 1 May 1984. The polyurethanelined pond is $45 \mathrm{~cm}$ deep and of $50 \mathrm{~m}^{3}$ capacity. The raw domestic sewage was supplied at a rate resulting in a retention time of 5 days. The water in the pond is mixed and aerated by a cage aerator driven by a 1-HP electric motor. Chlorophyll $a$ was determined spectrophotometrically and fluorometrically. Dissolved inorganic carbon (DIC) was measured by modified alkalinity method (Standard Methods, 1971). Light measurements were taken by a LiCor-185 light meter operating in a quantum mode equipped with an underwater sensor. The readings were taken at $5-\mathrm{cm}$ intervals to the depth of $30 \mathrm{~cm}$. The primary productivity measurement methods are described below, separately for each investigator.

\section{${ }^{14} \mathrm{C}$ horizontal test-tube ladders (T.Berner)}

Since the ordinary enclosures used for the measurement of primary productivity of phytoplankton by ${ }^{14} \mathrm{C}$ are far too bulky for the detailed analysis of the photosynthetic profile of a shallow euphotic zone like that found in a high-rate oxidation pond (HROP), 
a special rack using Pyrex test-tubes has been developed (Berner et al., 1979). The vertical separation between the tubes is set to $5 \mathrm{~cm}$. To facilitate easy insertion and removal of the tubes, the 'steps' are made of flexible PVC. Each such step accommodates two test-tubes, a clear one on the outside and a black-painted one on the inside. The steps are mounted on a stainless steel 'ladder' attached with a clamp to a stand. Each test-tube is filled with $15 \mathrm{ml}$ of pond water. To facilitate the injection of the $\mathrm{NaH}^{24} \mathrm{CO}_{3}$ solution at the beginning of the incubation and fixative at its end, the test-tubes are stoppered with serum caps. Such a design greatly reduces the exposure to light before and after the incubation period. To each test-tube $1.8 \mu \mathrm{Ci}{ }^{14} \mathrm{C}$-bicarbonate was added. Exposure time was $60 \mathrm{~min}$, after which DCMU was injected to stop the incorporation. This process was followed by filtration of two subsamples of $5 \mathrm{ml}$ from each depth through glass filter paper (GFC-Whatman). The filters were acidified by fuming over concentrated $\mathrm{HCl}$ and counted on a Packard Tri-Carb Scintillation Counter. Photosynthesis $\left(\mathrm{P}_{\mathrm{z}}\right)$ at each depth was calculated according to Vollenweider (1973).

\section{${ }^{14} \mathrm{C}$ size fractionation-acid bubbling method (U. Uehlinger)}

Exposure time was 09.10-11.10 am. To $100 \mathrm{ml}$ glass-stoppered Pyrex bottles filled with pond water about $4 \mu \mathrm{Ci} \mathrm{NaH}{ }^{14} \mathrm{CO}_{3}$ were added. The bottles were exposed at the following depths: surface, $0.12 \mathrm{~m}$ and $0.24 \mathrm{~m}$. After an exposure of $2 \mathrm{~h}$ the samples were filtered through a Nittex screen (30 $\mu \mathrm{m}$ mesh size) and Nucleopore filters $(12,3 \mu \mathrm{m}) .{ }^{14} \mathrm{C}$ assimilation was determined according to Gachter and Mares (1979) -acid bubbling method. The primary production was calculated as follows:

$$
\begin{aligned}
& \text { prod. }=\frac{{ }^{14} \mathrm{C} \text { assimilated-background }}{{ }^{14} \mathrm{C} \text { available-background }} \times 1.06 \times \mathrm{TIC} \frac{1}{t} \\
& \text { TIC (Total Inorganic Carbon) }=74.99 \mathrm{mg} \mathrm{C}^{-1} \quad t=2 \mathrm{~h}
\end{aligned}
$$

Determination of background was done according to Gächter et al. (1984).

\section{${ }^{14} \mathrm{C}$ size fractionation-filtration method (H.Rai)}

Five-milliliter subsamples were obtained from each test-tube used in the 'ladder' (see T.Berner for details) after the 1-h incubation period. Samples were brought back to the laboratory in a light-tight box and immediate fractionation was started. During the process of fractionation the samples were stored in the cold and in total darkness until the fractionation was completed.

Fractionation was carried out (after incubation) by filtering the samples through $30 \mu \mathrm{m}$, $12 \mu \mathrm{m}$, Nytal screen $3 \mu \mathrm{m}$ and $0.8 \mu \mathrm{m}$ Nucleopore filter, $50 \mathrm{~mm}$ diameter, respectively, under diffused light and without applying any pressure. The activity added to the samples was estimated by directly adding a $1 \mathrm{ml}$ aliquot in a scintillation vial containing $4 \mathrm{ml}$ of cocktail. The activity was determined by liquid scintillation counter. The filters were placed in scintillation viais containing $4 \mathrm{ml}$ of cocktail and were also counted on the Packard Tri-Carb Liquid Scintillation Counter. Total carbon assimilated was calculated according to Vollenweider (1973). 
Oxygen evolution method, measured by Clark-type electrode (F.Schanz, Z.Dubinsky and P. Falkowski).

Oxygen evolution was measured in a special thermostatted $\left( \pm 0.05^{\circ} \mathrm{C}\right)$ cuvette with a Clark-type oxygen electrode (Yellow Springs Instruments). The light source was a quartz-halogen lamp capable of providing an irradiance of up to $2000 \mu \mathrm{E} \mathrm{m}^{-2} \mathrm{sec}^{-1}$. Irradiance levels were measured by a LiCor 185 light meter with a air quantum sensor. The signal from the electrode was amplified by a custom built variable-gain amplifier and plotted on a $10 \mathrm{mV}$ full-scale recorder.

\section{Model of primary productivity (J.U.Grobbelaar)}

A model for predicting algal productivity in clean algal systems was calibrated and verified by Grobbelaar (1981). This model was refined and tested against 18 months of data collected from clean algal cultures operated at Dortmund, Federal Republic of Germany (Grobbelaar et al., 1984). The model has the generalized format of:

Productivity $\left(\mathrm{mg} \mathrm{C} \mathrm{m}^{-2} \mathrm{~h}^{-1}\right)=$ Production-Respiration-Inhibition

Production is calculated as the temperature and light response of biomass from the following equation:

$$
\text { Production }\left(\mathrm{mg} \mathrm{C} \mathrm{m}^{-2} \mathrm{~h}^{-1}\right)=\left[A_{1} \cdot X_{1} \cdot\left(A_{2}{ }^{T}\right)\right] \cdot\left[I \cdot B S \cdot\left(A_{3}{ }^{T}\right) / I+B S \cdot\left(\mathrm{A}_{3}{ }^{T}\right)\right]
$$

where

$$
\begin{array}{lll}
A_{1} & = & 0.066 \text { (maximum light utilization efficiency) } \\
A_{2} & = & 1.3 \text { (temperature coefficient of photosynthesis) } \\
A_{3} & = & 1.5 \text { (temperature coefficient of light half saturation) } \\
T & = & \text { temperature factor calculated from }(t-10) / t \text { where } t=\text { measured } \\
& \text { temperature in }{ }^{\circ} \mathrm{C} \\
I & = & \text { irradiance in } \mathrm{E} \mathrm{in}^{-2} \mathrm{~h}^{-1}(\mathrm{E}=\text { Einsteins) } \\
B S\left(A_{3} T^{2}\right)= & \text { temperature dependance of light half saturation constant where } \\
& B S=0.6 \\
X_{1}= & \text { biomass in } \mathrm{mg} \text { per } 10 \mathrm{~mm} \text { depth and } 1 \mathrm{~m}^{2}
\end{array}
$$

The component 'Respiration' represents a total loss factor and includes organic excretion by algae, and is calculated from the following equation:

$$
\text { Respiration (mg C m } \left.{ }^{-2} \mathrm{~h}^{-1}\right)=X_{1} \cdot\left\{\left[\left(A_{4}{ }^{T}\right)-0.54\right] / 100\right\}
$$

where $A_{4}=1.5$ (temperature coefficient of total losses).

Photoinhibition is a well-documented phenomenon (Harris, 1978) and depends on the intensity, quality and duration of irradiance. It was considered to be an important loss factor and therefore included in the model of Grobbelaar et al. (1984). It is calculated from the following equation:

$$
\text { Inhibition }\left(\mathrm{mg} \mathrm{C} \mathrm{m}^{-1} \mathrm{~h}^{-1}\right)=\text { Production } \cdot\left[\left(A_{5} T / 75\right) \cdot I\right]
$$

where $A_{5}=2.5$ (temperature coefficient of photuinhibition).

Photoinhibition was considered to influence only newly produced material and is 


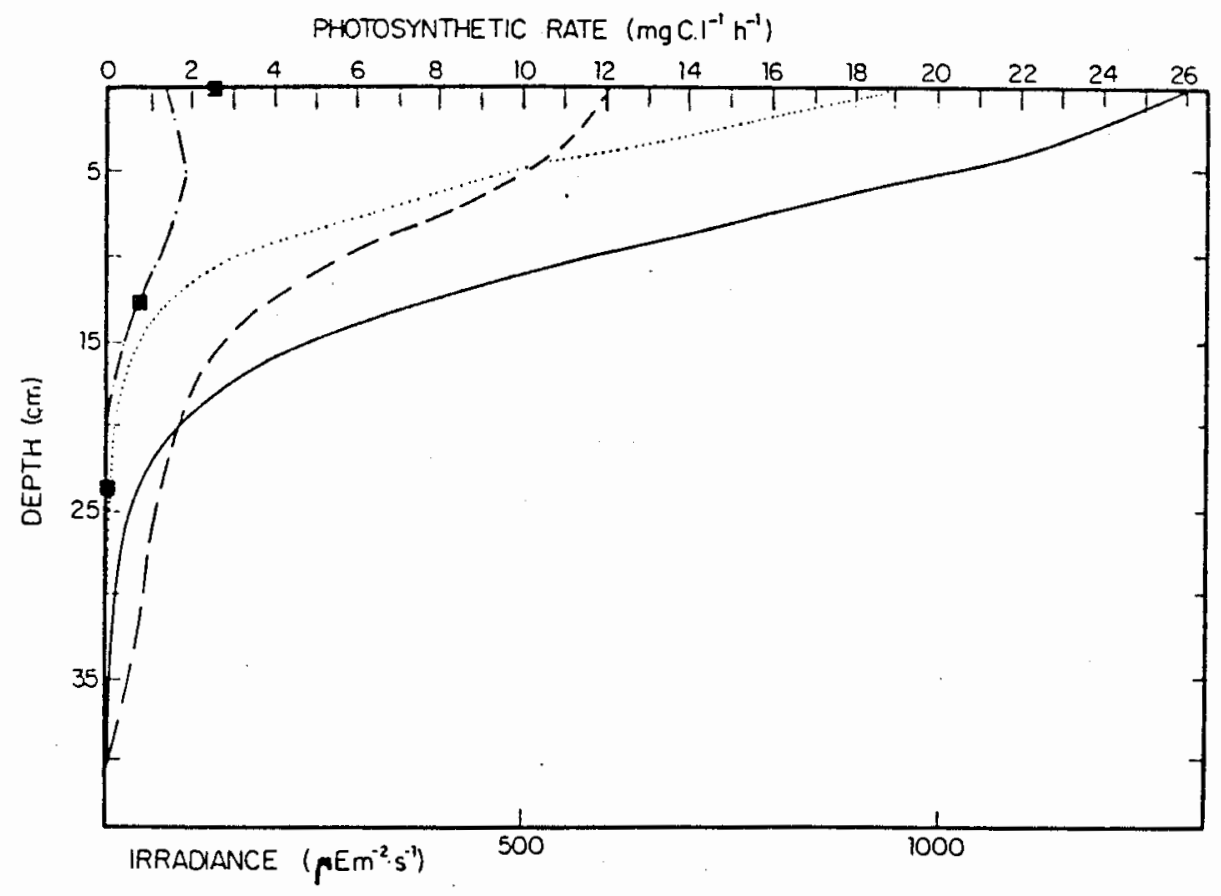

Fig. 1. Photosynthesis versus irradiance in the high-rate oxidation pond (HROP). . . . ., light; $\mathrm{O}_{2}$ evolution; - - - - .... ${ }^{14} \mathrm{C}$ incorporation; $\mathrm{E}$, size fractionation.

therefore a portion of Equation 2. A condition is also built into the model where Equation 4 becomes zero at irradiances less than $1 \mathrm{E} \mathrm{m}^{-2} \mathrm{~h}^{-1}$. Equation 4 represents a mere conceptual view of photoinhibition and needs to be confirmed or rejected by experimental evidence.

The model calculates productivity for a surface area of $1 \mathrm{~m}^{-2}$ at $10-\mathrm{mm}$ depth intervals until the bottom of the pond is reached. From a surface irradiance value and the biomass, the attenuation of light over the depth profile is calculated and the light intensity at each specific 10-mm depth interval is then used in the calculation. The total of all $10-\mathrm{mm}$ depth intervals for the entire profile represents the integral productivity.

The above model was used to calculate production rates in the high-rate algal pond for the period $09.00-10.00$, and $14.30-15.00 \mathrm{~h}$ on 1 May 1984 .

An extremely important aspect of the model is that it assumes the algae to be in adapted state conditions. A physiological state is assumed which does not change with time, is independent of specific composition and performance and will always render exactly the same results for a given set of conditions. Quantification of the loss rates in the 'Respiration' and 'Inhibition' components of the model were difficult. Rates of dark respiration ranging from 1.4-44\% have been reported (Gibbs, 1962), excretion of up to $60 \%$ and more of assimilated carbon has been measured (Heilebust, 1974) and percentage photo-inhibition of $75 \%$ and more is commonly found (Harris, 1978). The role and magnitude of photorespiration, decay, photo-oxidation, mixotrophic growth, etc., 


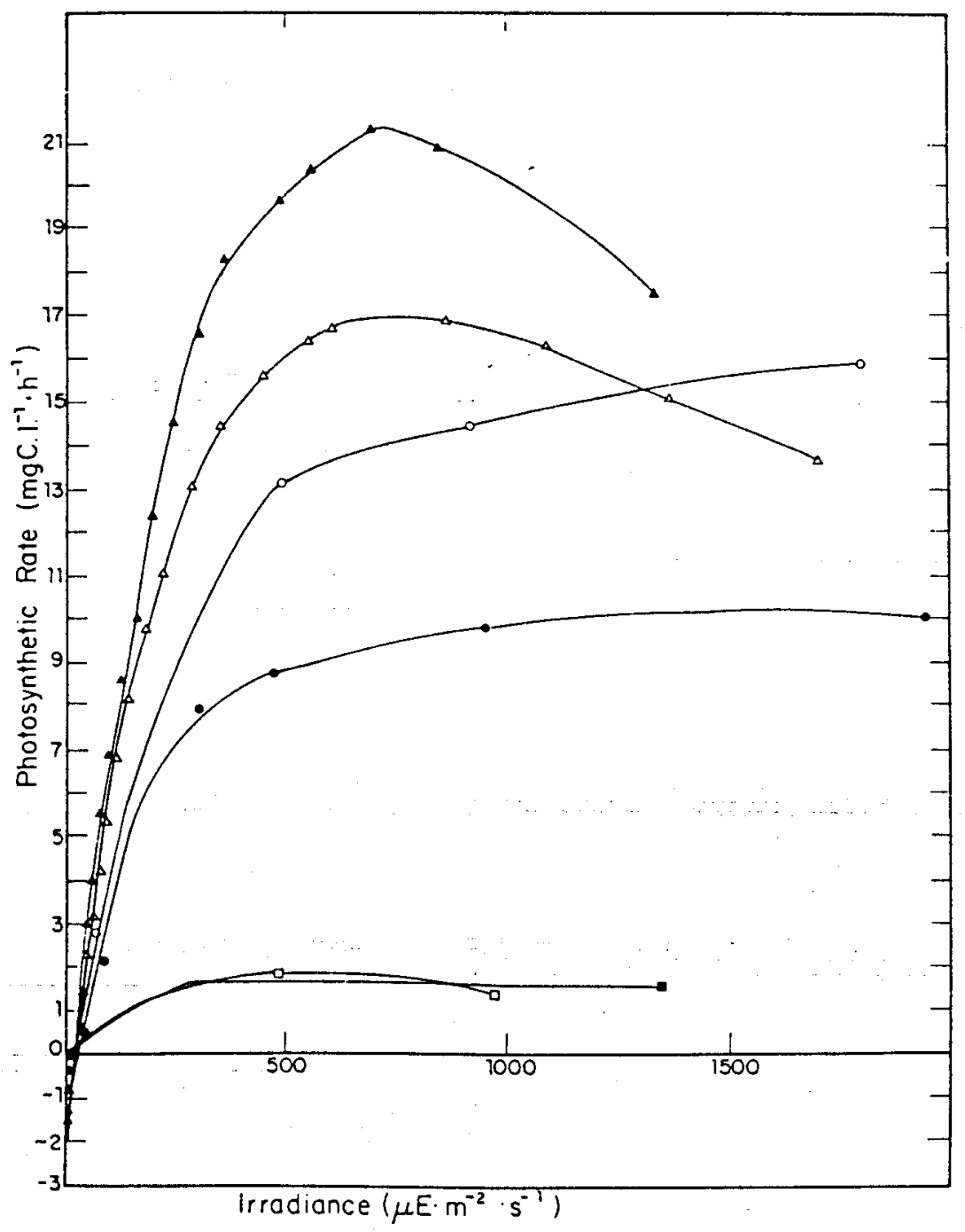

Fig. 2. Photosynthetic profiles in HROP: $\boldsymbol{\Delta}-\boldsymbol{\Delta}-\boldsymbol{\Delta}$, model (Grobbelaar) (afternoon); $\Delta-\Delta-\Delta$, model (Grobbelaar) (morning); $\mathrm{O}-\mathrm{O}-\mathrm{O}, \mathrm{O}_{2}$ evolution (Schanz) (morning); $\bullet-\bullet-\bullet$, (Schanz) (afternoon); $\square-\square-\square,{ }^{14} \mathrm{C}$ incorporation (Berner) (morning); $\mathbf{\square}-\mathbf{\square}-\mathbf{\square},{ }^{14} \mathrm{C}$ incorporation (Berner) (afternoon).

are unknown in mass outdoor cultures. For this reason, equations 3 and 4 are generalized loss components, embracing all losses, many of which are unknown and require investigation.

\section{Results and Discussion}

The comparison of GAP II experimental results from the heterotrophic, dense algal ponds at the Technion raises considerable questions concerning the adequacy of our 


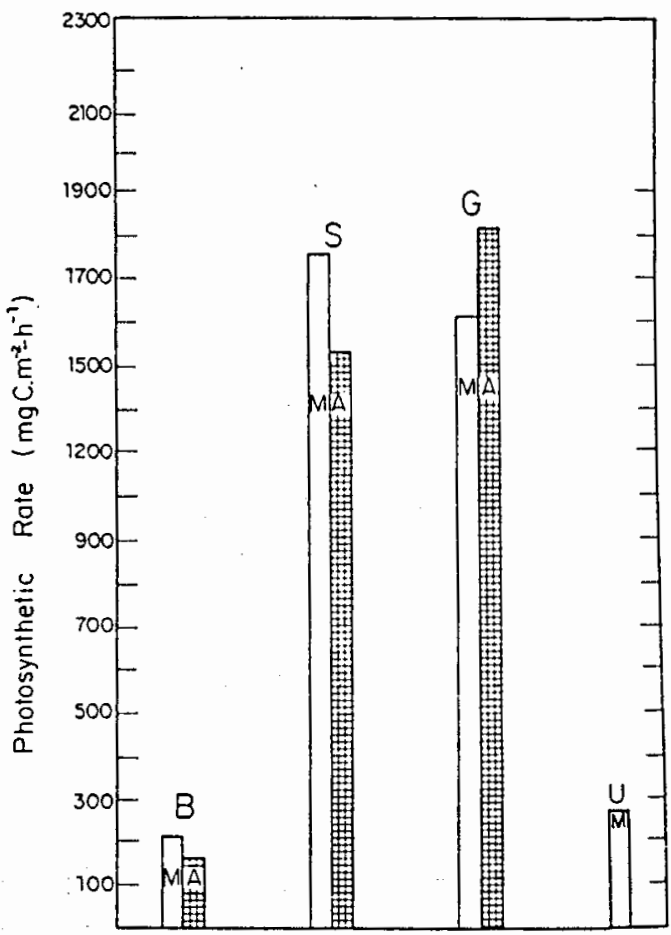

Fig. 3. Areal primary productivity in HROP. $\mathrm{M}$ - morning; $\mathrm{A}-$ afternoon, $\mathrm{B}-{ }^{14} \mathrm{C}$ incorporation (Berner); $\mathrm{G}$ - model (Grobbelaar); $\mathrm{S}-\mathrm{O}_{2}$ evolution (Schanz); $\mathrm{U}$ - size fractionation (Uehlinger).

methodologies in dealing with such systems. The most striking discrepancies are those between the $\mathrm{O}_{2}$ electrode and ${ }^{14} \mathrm{C}$ test-tube procedures (Figures $1-3$ ). At all depths, or irradiances, photosynthetic rates measured by the $\mathrm{O}_{2}$ electrode were an order of magnitude above those obtained by the ${ }^{14} \mathrm{C}$ test-tubes. Such a difference may be due to a combination of factors.

The intense stirring of algae in the experimental $\mathrm{O}_{2}$ electrode chamber greatly enhances photosynthesis by facilitating supply of $\mathrm{CO}_{2}$ and removal of $\mathrm{O}_{2}$ in the cellular microenvironment. This situation may be more similar to that experienced by the cells in the mixed high-rate oxidation pond than that within static test-tubes or flasks.

Moreover, the enclosed, dense algal and bacterial populations may result in violation of some important assumptions of ${ }^{14} \mathrm{C}$ tracer methodology. During the 1 -h incubations, two processes were probably occurring, both further reducing apparent photosynthetic rates: reduction in total available inorganic carbon and fast recycling of respired ${ }^{14} \mathrm{C}$ within the vessels.

Indeed, in a previous study of dense algal ponds (Berner and Dubinsky, 1976) (Figure 4), a steep decline in ${ }^{14} \mathrm{C}$ assimilation rates was found as duration of incubation periods increased from 5 to $40 \mathrm{~min}$. The difference in photosynthetic rates found in this experiment is similar in magnitude to the one reported in the present study between the $\mathrm{O}_{2}$ electrode and ${ }^{14} \mathrm{C}$ methods. Since the residence time of the algae in the $\mathrm{O}_{2}$ chamber at any one light intensity was limited to $3-5 \mathrm{~min}$, the present difference 


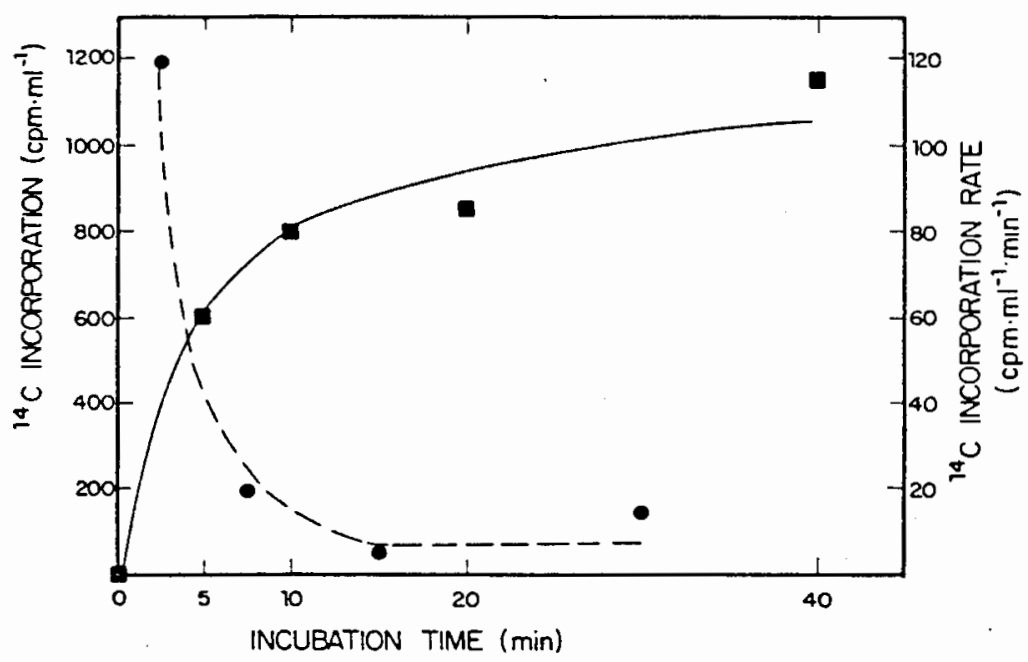

Fig. 4. Time course of ${ }^{14} \mathrm{C}$ incorporation by algal mass culture (adapted from Berner and Dubinsky, 1976). E- - - . ${ }^{14} \mathrm{C}$ incorporation $\left(\mathrm{cpm} \mathrm{ml}^{-1}\right) ; \bullet \cdots \bullet \cdots,{ }^{14} \mathrm{C}$ incorporation rate $\left(\mathrm{cpm} \mathrm{ml^{-1 }} \mathrm{min}^{-1}\right)$.

between the $\mathrm{O}_{2}$ and the ${ }^{14} \mathrm{C}$ study may, to a great extent, represent the remarkable reduction in assimilation rates with duration of the experiment so obvious in Figure 4.

Further reduction in areal integral of photosynthesis in the ${ }^{14} \mathrm{C}$ test-tube method might be caused by the $-25 \%$ photoinhibition apparent in the upper test-tube. This phenomenon was totally absent in the $\mathrm{O}_{2}$ electrode 'profile' (Figure 1) reconstructed from the $P$ versus $I$ curve at corresponding light depths (Figure 2). A possible reasen for the reduction or absence of photoinhibition in the oxygen chamber might be due, at least in part, to the spectral difference between sunlight and the somewhat 'redder' light of quartz-halogen source. It may be argued whether algae forced to travel between extreme light intensities do ever experience light inhibition. The comparison of results in this study seems to favor a conclusion that only in cases when a stable, stratified water column entrains algal populations for long periods at extremely high irradiances, does photoinhibition occur, occasionally followed by photodynamic death (Eloff $e t a l$, 1976).

In general, the computer simulation model predicts gross photosynthetic rates even above those found by the $\mathrm{O}_{2}$ method, although the model includes a near-surface light inhibition term.

The model was used to calculate production rates in the 'high-rate' algal pond situated at the Technion (Haifa, Israel) for the periods $09.00-10.00 \mathrm{~h}$ on 1 May 1984. Figure 1 includes the production rates predicted by the model for the morning experimental results, while Figure 3 compares the net areal production predicted for both times.

Computed areal productivity was $1615.36 \mathrm{mg} \mathrm{C} \mathrm{m}^{-2} \mathrm{~h}^{-1}$ in the morning and $1817.21 \mathrm{mgC} \mathrm{m}^{-2} \mathrm{~h}^{-1}$ in the afternoon. Although less light was measured at the surface of the culture in the afternoon, the culture temperature was $6^{\circ} \mathrm{C}$ warmer than in the morning. This temperature difference caused the higher productivity calculated for the afternoon experiment.

The results shown in these figures highlight one of the problems when dealing with 
Table I. Primary production and subsequent size fractionation by filtration in the Technion HROP, Haifa, Israel, I May 1984 (H.Rai)

\begin{tabular}{lcc}
\hline $\begin{array}{l}\text { Size fraction } \\
\mu \mathrm{m}\end{array}$ & $\begin{array}{l}\text { Primary production } \\
\mathrm{mg} \mathrm{C} \mathrm{m}^{-3} \mathrm{~h}^{-1}\end{array}$ & Percentage composition \\
\hline$>30$ & 1204 & 56 \\
$<30$ & 936 & 43 \\
$<12$ & 860 & 40 \\
$<3$ & 836 & 39 \\
$<0.8$ & 46 & 2 \\
Total particulate production & 2140 & 100 \\
$\quad(>30+<30)$ & & $2 \%$ of particulate \\
Photosyntheticaily dissolved & 44 & production \\
organic compound (PDOC) & & \\
Total production [particulate & 2184 & \\
and dissolved (PDOC)] & & \\
\hline
\end{tabular}

Table Il. Primary production of different size classes measured by the acid bubbling method in the Technion HROP, I May 1984 (U.Uehlinger)

\begin{tabular}{|c|c|c|c|c|c|}
\hline & \multicolumn{5}{|c|}{ Size fractions } \\
\hline & Total & $<30 \mu \mathrm{m}$ & $<12 \mu \mathrm{m}$ & $<3 \mu \mathrm{m}$ & $<0.8 \mu \mathrm{m}$ \\
\hline $\begin{array}{l}\text { Production in } 0-0.4 \mathrm{~m} \\
\mathrm{mg} \mathrm{C} \mathrm{m} \mathrm{m}^{-3} \mathrm{~h}^{-1}\end{array}$ & 294 & 307 & 314 & 159 & 98 \\
\hline Percent of total production & 100.0 & 104.4 & 106.8 & 54.1 & 33.3 \\
\hline $\begin{array}{l}\text { Production in } 0 \mathrm{~m} \\
\mathrm{mg} \mathrm{C} \mathrm{m}^{-3} \mathrm{~h}^{-1}\end{array}$ & 2514 & 2580 & 2549 & 1603 & 1035 \\
\hline
\end{tabular}

'high-rate' algal ponds where a large aphotic zone is present (Grobbelaar, 1982). This results in considerable losses, as seen below $0.2 \mathrm{~m}$ depth, severely limiting the efficiency of light utilization. According to Grobbelaar (1982), the optimal biomass density for a $0.4 \mathrm{~m}$ deep pond, for maximal productivity should be about $110 \mathrm{mg} \mathrm{l}^{-1}$.

The comparison between the $\mathrm{O}_{2}$ electrode results and the model shows that they agree fairly well in their estimates of dark respiration rates $\left(2.49\right.$ and $2.043 \mathrm{mg} \mathrm{l}^{-1} \mathrm{~h}^{-1}$, respectively). It is, however, hard to reconcile the high values assigned to gross photosynthesis by the model with either the measured $\mathrm{O}_{2}$ electrode values or with previous, independent data derived from direct harvesting of the algae under similar operation regimes of the pond. These values in the same pond average $5-12 \mathrm{~g} \mathrm{C} \mathrm{m}^{-2} \mathrm{day}^{-1}$ (Shelef et al., 1980), values well below the present model's prediction $\left(-20 \mathrm{~g} \mathrm{C} \mathrm{m}^{-2}\right.$ day $^{-1}$ ).

The comparison of morning against afternoon data measured by the $\mathrm{O}_{2}$ method to those predicted by the model may indicate a source of overestimate by the latter.

The values measured by the $\mathrm{O}_{2}$ electrode correspond very well with numerous studies (Falkowski et al., 1984) showing 'afternoon naps', hysteresis effects and related decreases in photosynthetic rates with the total duration of daytime. This trend is also evident in the ${ }^{14} \mathrm{C}$ test-tube results (Figure 3). The model does not incorporate these 
effects leading to a prediction of higher photosynthesis in the afternoon than in the morning, due to the rise in water temperature. This might further increase estimates of overall diurnal photosynthetic rates.

The results of the size fractionation study are compiled in Table I. The slightly increased production of the $<30$ and $<12 \mu \mathrm{m}$ fractions is in the error range of the total production and may be caused by continuing photosynthesis, since the samples could not be processed in dim light. The production of the $<0.8 \mu \mathrm{m}$ fraction may be overestimated due to leaching effects because the fractionation of the extremely dense algal suspension required a filtration procedure of approximately $20 \mathrm{~mm} \mathrm{Hg}$ in this pore-size range. The acid bubbling method yielded a $15 \%$ higher value of the total production than the filtration method, which is in agreement with findings of Gächter et al. (1984). This difference is increasing with consecutive fractionation. The stress of filtration through a $0.2 \mu \mathrm{m}$ filter, in addition to the fractionation procedure, may cause enhanced cell damage and therefore an apparent lower production when the filtration method is used.

There is almost no difference between the two methods used for size fractionation study (Tables I and II). Rai's experiments were carried out at $0 \mathrm{~m}$ level and the primary production value is $2.141 \mathrm{mg} \mathrm{Cl}^{-1} \mathrm{~h}^{-1}$ (Table I). This value is in the same order of magnitude as the other ${ }^{14} \mathrm{C}$ incorporation experiments performed by Berner $(1.450 \mathrm{mg}$ $\left.\mathrm{C}^{-1} \mathrm{~h}^{-1}\right)$ (Figure 1) and Uehlinger (2.514 $\mathrm{mg} \mathrm{Cl}^{-1} \mathrm{~h}^{-1}$ ) (Table II).

This study emphasizes the importance of nannoplanktonic algae for the biomass production high-rate oxidation ponds. The nannoplanktonic algae would be used for zooplankton growth and this, in turn would facilitate the growth of fingerlings in the fish-pond culture systems. Thus the high-rate oxidation ponds, if available near the fish-culture ponds, might increase the fish growth, and at the same time the ponds could be used for the treatment of sewage. Thereby there will be quick recycling of the domestic sewage and optimal ultilization of energy.

We might conclude that high-rate oxidation ponds and other hypertrophic water bodies are ideal systems where different methodologies for measuring primary productivity can be effectively tested. The dense algal populations and high rates of photosynthesis amplify differences between methods and point out otherwise hidden difficulties and potential pitfalls.

Our study clearly indicates that ${ }^{14} \mathrm{C}$ incorporation may be used with dense algal populations only when incubation times can be kept very short, preferably within 5 min or less (Figure 4). This restriction is, however, extremely difficult to comply with, since it increases the relative importance of timing errors and pre- and post-incubation exposure to surface light prior to processing of samples.

The present study stresses the unfulfilled potential of oxygen electrode methods especially suited to dense algal populations. Unfortunately, at present, most $\mathrm{O}_{2}$ electrodes require rather forceful stirring to account for their own oxygen consumption. This stirring may create within the experimental chamber better conditions to photosynthesis than those found in the 'real' outside waters.

\section{References}

Aaronson,S., Berner, T. and Dubinsky,Z. (1980) Microalgue as a source of chemicals and natural products.

In Shelef.G. and Soeder.J. (eds), Algae Biomass: Production and Use, Elsevier. Amsterdam. pp. 531 -546. 
Anderson,G.C. (1965) Fractionation of phytoplankton communities of the Washington and Oregon coasts. Limnol. Oceanogr., 19, 477-480.

Benemann,J.. Koopman.B., Weissman,J., Eisenberg,D. and Goebel,D. (1980) Development of microalgae harvesting and high-rate pond technologies in Califormia. In Shelef,G. and Soeder,J. (eds), Algae Biomass: Production and Use. Elsevier, Amsterdam, pp. 457-496.

Berman, T. (1975) Size fractionation of natural aquatic populations associated with autotrophic and hetereatrophic carbon uptake. Mar. Biol., 33, 215-220.

Bemer, T. and Dubinsky,Z. (1976) Combined systems for algal production and wastewater reclamation. Progress Report, Bar-Ilan University, Dept. of Life Sicences, Israel.

Berner, T., Dubinsky,Z. and Shelef,G. (1979) Problems and solutions in the measurement of primary productivity in photosynthetic sewage treatment systems. Isr. Ecol. Soc., Proceedings 10th Scientific Conference, A64-A77.

Berner. T., Dubinsky,Z. and Aaronson,S. (1980) The total lipid content of microaigae and its use as a potential lipid source for industry. In San Pietro,A. (ed), Biosaline Research. Plenum Press, New York, pp. $439-442$.

Burlew.J.S. (ed.) (1953) Algal Culture from Laboratory to Pilot Plant. Publication No. 600, Washington, D.C., Camegie Institute of Washington.

Conover.R.J. (1978) Transformation of organic matter. Mar Ecol., 4, 221-499.

Dubinsky,Z., Aaronson,S. and Berner,T. (1980) Some economic consideration in the mass culture of microalgae. In Shelef,G. and Soeder.J. (eds), Algae Biomass: Production and Use. Elsevier, Amsterdam, pp. 819-832.

Dubinsky,Z., Berner,T. and Aaronson,S. (1978) Potential of large scale algal culture for biomass and lipid production in arid lands. Biotechnol. Bioeng. Symp. No. 8., 51-68.

Dubinsky,Z. and Aaronson,S. (1980) Review of the potential uses of microalgae. In San Pietro,A. (ed.), Biosaline Research. Plenum Press, New York, pp. 181-206.

Durbin,E.G., Krawiec,R.W. and Smayda,T.J. (1975) Seasonal studies on the relative importance of different size fractions of phytoplankton in Narragansett Bay (U.S.A.). Mar Biol., 32, 271-287.

Eloff,J.N., Steinitz,Y. and Shilo,M. (1976) Photooxidation of cyanobacteria in natural conditions. Appl. Environ. Microbiol.. 31, 119.

Eppley,R.W. and Sloan,P.R. (1966) Growth rates of marine phytoplankton. Correlation with light and absorption by cell chlorophyll $a$. Physiol. Plant, 19, 47-59.

Falkowski,P.G., Dubinsky,Z. and Santostefano,G. (1986) Light enhanced dark respiration in phytoplankton. Verh. Int. Verein Limnol., in press.

Gaarder,T. and Gran,H.H. (1927) Investigations of the production of plankton in the Osio Fjord. Rupp. Proc. Verb. Cons. Int. Explor. Mer., 42, 3-48.

Gächter,R. and Mares,A. (1979) Comments on the acidification and bubbling method for determination of phytoplankton production. Oikos, 33, 69-73.

Gächter,R., Mares.A. and Tilzer,M.M. (1984) Determination of phytoplankton production by the radiocarbon method: a comparison between the acidification and bubbling method (ABM) and the filtration technique. J. Plankion Res., 6, 359-364.

Gibbs,M. (1962) Respiration. In Lewin,R.A. (ed.), Physiology and Biochemistry of Algae. Academic Press, pp. $61-90$.

Gilmartin,M. (1964) The primary production of British Columbia Fjord. J. Fish Res. Bd. Can., 21, 505-538.

Goldman,J.C. (1979a) Outdoor algal mass cultures. I. Applications. Water Res., 13, 1-19.

Goldman,J.C. (1979b) Outdoor algal mass cultures. II. Photosynthetic yield limitation. Water Res., 13, $119-136$.

Grobbelaar,J.U. (1981) Deterministic production model for describing algal growth in large outdoor mass algal cultures. In Grobbelaar,J.U., Soeder,C.J. and Toerien,D.F. (eds), Wastewater for Aquaculnure. Univ. of O.F.S., Publ. Series C, No. 3, pp. $1732-181$.

Grobbelaar.J.U. (1981) Open semi-defined systems for outdoor mass culture of algae. lbid., pp. 24-30.

Grobbelaar,J.U. (1982) Potential of algal production. Water S.A., 8, 79-85.

Grobbelaar,J.U., Soeder.C.J. and Stengel.E. (1984) Modelling algal productivity and oxygen production in large outdoor cultures. KFA Publication no. 282, 49 pp.

Harris.G.P. (1978) Photosynthesis, productivity and growth. The physiological ecology of phytoplankton. Arch. Hydrobiol. Bein.. Ergebn. Limnol, 10, 1-171.

Heaney.S.i. and Sommer, U. (1984) Changes of algal biomass as carbon, cell number and volume, in bottles suspended in Lake Constance. J. Plankton Res. 6, 239-247. 
Hellebust,J.A. (1974) Extracelluiar products. In Stewart,W.D.P. (eds), Algal Physiology and Biochemistry. Botanical Monographs, 10, 838-863.

Hendricks,D.W. and Pote.W.D. (1974) Thermodynamic analysis of a primary oxidation pond. J. Water Poll. Cont. Fed., 46. 333-351.

Herbland,A. and Boutellier,Le.A. (1981) The size distribution of phytoplankton and particulate organic matter in the Equatorial Atlantic Ocean: Importance of ultraseston and consequences. J. Plankton Res., 3, 650-665.

Hill,D.T. and Lincoln,F.P. (1981) Development and validation of a comprehensive model of large-scale production of microalgae. Agric. Wastes, 3, 43-64.

Holmes, R.W. (1968) Size fractionation of photosynthesizing phytoplankton. Special Scientific Report Fisheries, 279, 69-71.

Kalff,J. (1972) Net plankton and nannoplankton production and biomass in a north temperate zone lake. Limnol. Oceanogr., 17, 712-720.

Kristiansen,J. (1971) Phytoplankton of two Danish lakes, with special reference to seasonal cycles of the nannoplankton. Mitt Internat. Verein. Limnol., 19, 253-265.

Malone, T.C. (1971) The relative importance of netplankton and nannoplankton as primary producers in tropical oceanic and neritic phytoplankton communities. Limnol. Oceanogr., 16, 633-639.

Märkl,H. (1980) Modelling of algal production systems. In Shelef,G. and Soeder,J. (eds), Algae Biomass: Production and Use. Elsevier, Amsterdam, pp. 361-383.

Melack,J.M. and Kilhan,P. (1974) Photosynthetic rates of phytoplankton in East African alkaline, saline lakes. Limnol. Oceanogr., 19,743-755.

Mohn,F.H. (1980) Experience and strategies in the recovery of biomass from cultures of microalgae. In Shelef,G. and Soeder,J. (eds), Algae Biomass: Production and Use. Elsevier, Amsterdam. pp. 547-571.

Moraine,R., Shelef,G., Sandbank.E., Bar-Moshe,Z. and Shvarzzburd,L. (1980) Recovery of sewage-borne algae. Flocculation and centrifugation techniques. In Shelef.G. and Soeder,J. (eds), Algae Biomass. Production and Use. Elsevier, Amsterdam, pp. 531-546.

Munawar,M. and Munawar,I.F. (1975) The abundance and significance of phytoflagellates and nannoplankton in the St. Lawrence Great Lakes. I. Phytotlagellates. Verh. Internat. Verein. Limnol. 19, 705-723.

Munaware,M. and Burns,H.M. (1976) Relationship of phytoplankton biomass with absolute nutrients, primary production and chlorophyll $a$ in Lake Erie, 1970. J. Fish Res. Bd. Can., 33, 601-611.

Oswald,W.J. (1963) The high-rate pond in waste disposal. Dev. Ind. Microbiol., 4, 112-119.

Oswald,W.J. and Gotaas,H.B. (1955) Photosynthesis in sewage treatment. J. San. Eng. Div., 81, 1-34.

Paerl,H.W. and Mackenzie,L.A. (1977) A comparative study of the diurnal fixation pattern of nanoplankton and netplankton. Limnol. Oceanogr., 22, 732-738.

Parson,T.R. and Lebrasseur,R.J. (1970) The availability of food to different trophic levels in the marine food chain. In Steele,J.H. (ed.), Marine Food Chains. Oliver and Boyd, pp. 325-343.

Pavoni,M. (1963) Die Bedeutung des nannoplanktons in vergleich zum Netzplankton. Schweiz. Z. Hydrol., 25. $219-341$.

Rai,H. (1982) Primary production of various size fractions of natural phytoplankton communities in a North German lake. Arch Hydrobiol., 95, 395-412.

Rai,H. (1984) Release of photosynthetically produced dissolved organic carbon by natural phytoplankton populations in Schöhsee. Verh. Internat. Verein. Limnol., 22, 936-942.

Sakamoto,M., Tilzer,M.M., Gächter,R., Rai,H., Collos,Y., Tschumi,P., Berner,P., Zbären,D., Zbären,J., Dokulil,M., Bossard.P., Uehlinger,U. and Nutsch,E.A. (1984) Joint field experiments for comparisons of photosynthetic production. J. Plankron Res., 6, 365-383.

Shelef,G., Azov,Y., Moraine,R. and Oron,G. (1980) Algal mass production as an integral part of a wastewater treatment and reclamation system. In Shelef,G. and Soeder,J. (eds), Algae Biomass: Production and Use. Elsevier, Amsterdam, pp. 163-189.

Shelef.G. and Soeder,C.J. (eds), Algae Biomass: Production and Use. Elsevier, Amsterdam, pp. 163-189.

Shelef,G. and Soeder,C.J. (eds) (1980) Algae Biomass: Production and Use. Elsevier, Amsterdam.

Shelef,G. (1982) High-rate algae ponds for wastewater treatment and protein production. Water Sci. Tech., 14, $439-452$.

Soeder,C.J. (1980) The scope of microalgae for food and feed. In Shelef,G. and Soeder,J. (eds), Algae Biomass: Production and Use. Elsevier, Amsterdam. pp. 9-20.

Standard Methods for the Examination of Water and Wastewater (1971) APHA, Washington, 874 p.

Steemann Nielsen, E. (1952) The use of radiuactive carbon $\left({ }^{14} \mathrm{C}\right)$ for measuring organic production in the sea. J. Cons. Int. Expl. Mer., 18, 117-140.

Talling.J.F., Wood,R.B., Prosser.M.V. and Baxter,R.M. (1973) The upper limit of photosynthetic produc- 


\section{T.Berner et al.}

tivity by phytoplankton; evidence from Ethiopian soda lakes. Freshwater Biol., 3, 53-76.

Toerien,D.F. (1981) Growth kinetic prediction of algal growth in mass cultivation systems. In Grobbelaar,J.U., Soeder,C.J. and Toerien,D.F. (eds), Wastewater for Aquaculturc. Univ. of O.F.S. Publ. Series C. No. 3, pp. $168-172$.

Vollenweider,R.A. (1969) A Manual on Methods for Measuring Primary Production in Aquatic Environment. IBP Handbook, No. 12, Blackwell Scientific Publications, Oxford and Edinburgh.

Received May 1985; accepted February 1986 